\title{
PENGEMBANGAN MODUL CAR SAFETY BERBASIS STELR-STEM SEBAGAI MEDIA PEMBELAJARAN GERAK DAN GAYA
}

\author{
SRI NURGIANTI NATAMIHARJA \\ Pascasarjana PMIPA, Universitas Indraprasta PGRI, Jakarta \\ e-mail: srinurgianti28@gmail.com
}

\begin{abstract}
ABSTRAK
Rendah nya kemampuan siswa SMP dan SMA pada bidang Matematika sains juga rendah nya minat mereka dalam memutuskan karir mereka dibidang STEM mendorong penelitian ini. Penelitian ini bertujuan untuk mengembangkan modul car safety berbasis STELR - STEM untuk pembelajaran fisika dan untuk menguji efektivitasnya dalam pembelajaran. Adapun jenis penelitian ini adalah Research and Development ( $\mathrm{R} \& \mathrm{D})$ atau penelitian pengembangan dengan menggunakan model 4D, yaitu Define (pendefinisian), Design (perancangan), Development (pengembangan) dan Disseminate (penyebaran). Modul yang diambil adalah modul car safety berbasis STELR-STEM yang digunakan sebagai media pembelajaran gerak dan gaya. Simpulan yang dihasilkan dari penelitian ini adalah (1) Dari hasil uji validasi didapat hasil $90 \%$ sehingga dapat disimpulkan bahwa produk pengembangan pada penelitian ini telah memenuhi kriteria kelayakan.Modul Car Safety dinyatakan valid oleh ahli, kategori sangat baik, (2) Dari hasil angket siswa didapat skor $86 \%$ mendapatkan respons sangat positif dalam uji coba terbatas, (3) Dalam uji efektivitas Rata-rata nilai tes kelas eksperimen lebih besar dari rata-rata nilai kelas kontrol, dengan selisih 11,modul Car Safety dinyatakan efektif digunakan dalam pembelajaran Kata kunci: Penelitian pengembangan, modul, stem, stelr
\end{abstract}

\section{ABSTRACT}

The low ability of junior and senior high school students in the field of Mathematics and Science equal to their low interest in deciding their career in the STEM field prompted this research. This study aims to develop module car safety STELR - STEM based for learning physics and to test its effectiveness in learning. The type of this research is Research and Development ( $R$ $\&$ D) or development research using the 4D model, namely Define , Design , Development and Disseminate. The car safety based STELR-STEM module - which is used as a medium for learning motion and force. The conclusions generated from this study are (1) From the results of the validation test obtained $90 \%$ results so that it can be concluded that the product development in this study has the eligibility criteria. The Car Safety module was declared valid by experts, very good category, (2) From the results of the questionnaire students got a score of $86 \%$ getting a very positive response in a limited trial, (3) In the effectiveness test the average test score of the experimental class is greater than the average value of the control class, with a difference of 11, the Car Safety module is declared effective in learning

Keywords: research and development, module, stem, stelr

\section{PENDAHULUAN}

Data hasil penelitian Program for International Student Assessment [PISA] yang menguji kemampuan siswa SMP dan SMA pada mata pelajaran matematika, sains dan membaca menunjukkan bahwa kemampuan siswa Indonesia dalam menjawab soal-soal PISA rendah dari tahun ke tahun. Hal senada dengan Hasil Trends in International Mathematics and Science Studies (TIMSS) 2011, nilai rata-rata sains kelas VIII hanya rata-rata 406 dan berada di posisi ke-40 dari 42 negara. Persentase siswa kita yang dapat menjawab soal tingkat rendah sebanyak $54 \%$, tingkat sedang sebanyak 19\%, tingkat tinggi sebanyak $3 \%$ dan tidak satupun siswa yang dapat menjawab tingkat lanjut sebanyak $(0 \%)$. Angka ini sangat memprihatinkan karena penguasaan terhadap matematika dan sains harus dimiliki setiap individu yang hidup dibad ke21, dimana ilmu pengetahuan dan teknologi terus berkembang begitu pesat yang menuntut generasi muda untuk berpikir inovatif dan kreatif dalam memecahkan masalah sains. 
Selain itu, data dari Australian Academy of Technology and Enginering (ATSE) menunjukan bahwa minat siswa untuk serta dalam pelajaran IPA pada kelas 11 dan 12 cenderung menurun (Cirkony,2014). Hal itu juga sejalan dengan menurun nya siswa yang tertarik untuk meneruskan karir di bidang sains dan teknologi. Karena para siswa tersebut menganggap bahwa sains tidak berhubungan dengan kehidupan mereka dan beberapa siswa beranggapan bahwa pembelajaran sains itu sulit.

Data -data tersebut menimbulkan kekhawatiran kita terhadap masa depan Pendidikan anak - anak Indonesia. Ketika sains dan teknologi berkembang semakin pesat tetapi minat siswa terhadap sains dan teknologi semakin menurun.Sumber literatur seperti salah satu contoh nya National Research Council (2015) mengungkapkan bahwa para siswa tidak siap untuk tenaga kerja dimasa depan kecuali sistem Pendidikan dapat lebih fokus terhadap Pendidikan STEM (Science, Technology, Enginering and Mathematics) sejak usia dini.

Dari uraian diatas, mengingat cukup besarnya prestasi STEM bagi kepentingan global, tidak heran bila kini banyak pengembangan kurikulum di beberapa negara yang berupaya meningkatkan STEM. Salah satu nya adalah Australia, melalui Australian Academy of Technology and Enginering (ATSE) pada tahun 2007 membuat program Science and Technology Leveraging Relevance (STELR) sebagai pengembangan Pendidikan berbasis STEM. STELR membuat pembelajaran STEM dengan membuat modul yang relevan dengan kehidupan sehari-hari, dengan pembelajaran STEM yang berbasis Inquiry dan siswa membuat karya berbasis STEM (Pentland, 2019).

Dengan adanya pembelajaran STEM yang dekat dengan kehidupan sehari-hari diharapkan siswa akan lebih aktif dalam pelajaran yang berhubungan dengan STEM. Juga diharapkan semakin banyak siswa yang memutuskan berkarir di bidang STEM yang akan menyelesaikan permasalahan global baik di lingkup social ataupun ekonomi (Crowder 2016). STELR membuat modul dan KIT pembelajaran berbasis STEM yang dekat dengan kehidupan sehari-hari. Dengan hal ini diharapkan siswa dapat lebih terhubung dengan pembelajaran sains dan meningkatan minat mereka pada pembelajaran sains.

Salah satu modul nya adalah modul Car Safety. Modul Car safety dalam program STELR terdiri dari materi, pertanyaan dan lembar kerja siswa yang aktifitas nya berhubungan dengan keselamatan kendaraan. Modul ini terkait dengan materii fisika Gerak dan Gaya yang ada pada kurikulum 2013 pengembangan 2017. Harapan nya dengan modul ini siswa dapat lebih mudah memahami materi gerak dan gaya karena menggunakan modul yang aktifitas nya terhubung dengan kegiatan sehari-hari. Dengan menghubungkan pelajaran STEM dengan kehidupan sehari - hari diharapkan siswa dapat lebih terhubung dengan pelajaran . Sehingga membuat mereka tertarik untuk belajar STEM lebih dalam lagi . Dan dapat meningkatkan minat mereka terhadap pelajaran sains dan memutuskan untuk berkarir di bidang STEM..

\section{METODE PENELITIAN}

Jenis penelitian ini adalah Research and Development (R\&D) atau Penelitian Pengembangan. Salah satu produk penelitian pengembangan adalah produk pendidikan. Adapun produk yang peneliti kembangkan adalah Modul Car Safety yaitu modul yang diadaptasi dari modul program STELR tetapi dikembangkan dengan menggunakan alat yang tersedia di sekitar kita. Peneliti memilih model yang dikemukakan oleh Thiagarajan, yang disebut Four D Models (Model 4D), yaitu Define(Pendefinisian), Design (Perancangan), Develop (Pengembangan) dan Disseminate (Penyebaran). Populasi dalam penelitain ini adalah siswa MTs Ibad Ar Rahman kelas VIII tahun pelajaran 2020/2021. Sampel dipilih dengan teknik purposive sampling. Adapun penelitian ini dilakukan dengan cara validasi modul, uji coba terbatas ,uji efektifitas modul dan survey terhadap siswa yang menggunakan modul.

\section{HASIL DAN PEMBAHASAN}

Hasil pengembangan penelitian ini membahas kevalidan dan efektifitas modul pada pembelajaran. Pengembangan modul ini dilakukan dengan menyesuaikan modul yang dibuat 
oleh STELR Australia dengan menggunakan bahan bahan yang lebih mudah didapat pada keseharian kita. Pengembangan dilakukan dengan D Models (Model 4D), yaitu Define(Pendefinisian), Design (Perancangan), Develop (Pengembangan) dan Disseminate (Penyebaran).

\section{Hasil Define}

Pada tahap define, dilakukan analisis yang meliputi 3 hal, yaitu analisis potensi,masalah dan kurikulum

- Analisis Potensi

Berdasarkan studi awal, penulis menganalisis potensi sekolah yang sesuai untuk pengembangan modul . Penulis memilih sekolah ini karena memang fasilitas dan prinsip sekolah yang mengedepankan pendidikan sains.

- Analisis Masalah

Pemasalahan yang ditemui di sekolah adalah nilai UH IPA khusus nya fisika yang rendah dan juga kurang nya modul IPA di laboratorium padahal laboratorium sudah cukup memadai.

- Analisis Kurikulum

Analisis kurikulum juga sangat penting dilakukan. Analisis ini berguna untuk memenuhi kebutuhan dalam pengembangan modul. Analisis kurikulum yang dimaksud adalah analisis KD (Kompetensi Dasar). KD yang peneliti ambil untuk pengembangan modul ini adalah sebagai berikut.

3.2 Menganalisis gerak lurus, pengaruh gaya terhadap gerak berdasarkan hukum Newton, dan penerapannya pada gerak benda dan gerak makhluk hidup 4.2 Menyajikan hasil penyelidikan pengaruh gaya terhadap gerak benda

KD tersebut digunakan untuk mencari modul STELR yang akan diadaptasi. Juga KD tersebut digunakan sebagai dasar untuk mencari peralatan yang sesuai dengan KD juga sesuai dengan kondisi sekolah dari segi reliabilitas juga segi keamanan nya. Sehingga modul tersebut akan mudah digunakan dan mudah dipahami.

\section{Hasil Design}

Ada 2 langkah pada tahap perancangan ini yaitu perumusan IPK (Indikator Pencapaian Kompetensi) dan Perumusan kerangka modul

- Perumusan IPK (Indikator Pencapaian Kompetensi)

IPK (Indikator Pencapaian Kompetensi) ini perlu dirumuskan terlebih dahulu. IPK ini berfungsi sebagai arah pembelajaran dana ranah pembelajaran ini perlu sebagai acuan pengembangan emodul. IPK ini dikembangkan berdasarkan KD (Kompetensi Dasar) seperti yang sudah dipaparkan pada tahap Define. Adapun IPK dapat dirumuskan sebagai berikut.

1. Peserta didik mampu menganalisis gerak benda dari data percobaan GLB dan GLBB

2. Peserta didik mampu menjelaskan pengertian gaya

3. Peserta didik mampu menyebutkan jenis gaya

4. Peserta didik mampu menerapkan Hukum I,II dan II Newton

5. Peserta didik mampu Menganalisis gerak makhluk hidup dan gerak benda berdasarkan Hukum I,II dan III Newton

- Perumusan Kerangka modul

Setelah IPK sudah ditentukan, langkah berikutnya adalah membuat kerangka modul. Secara umum, kerangka modul terdiri dari pendahuluan, kegiatan pembelajaran dan evaluasi

\section{Hasil Develop}

Tahap ketiga dari penelitian pengembangan adalah Develop atau pengembangan. Pada tahap ini adalah dimulainya memproduksi atau membuat modul Car Safety. Tahap Develop ini terdiri dari 3 langkah, yaitu pembuatan modul, validasi modul, uji coba. 


\section{1) Pembuatan modul Car Safety}

Modul car safety yang digunakan peneliti merupakan modul yang diadaptasi dari STELR tetapi disesuaikan dengan kondisi sekolah dari segi peralatan maupun pelaksanaan nya. Berikut adalah isi modul

- Daftar Isi ; menjadi petunjuk bagi siswa untuk menggunakan modul

- Pendahuluan : yang berisi materi dan masalah yang kita hadapi sekarang ini di Indonesia terkait keamanan kendaraan . Pendahuluan ini tentu saja telah disesuaikan dari modul asli nya yang memuat persoalan di Australia

- lembar kegiatan : berisi petunjuk siswa dalam melaksanakan kegiatan yang berhubungan dengan keamanan kendaraan . seperti bagian pendahuluan, bagian kegiatan siswa ini pun sudah dikembangkan dari segi peralatan nya. Alat yang digunakan menyesuaikan dengan ketersediaan alat di sekitar sekolah kami.

- lembar evaluasi. : mengevaluasi sejauh mana siswa memahami konsep dari kegiatan yang dilakukan

2) Validasi modul

Untuk kualitas dan keabsahan modul diperlukan validasi yang dilakukan oleh para ahli. Para ahli di sini terdiri dari 3 ahli, yaitu ahli bahasa, ahli materi dan ahli evaluasi. Adapun hasil validasi adalah sebagai berikut.

Tabel 1 Hasil Validasi Modul

\begin{tabular}{llc} 
No & \multicolumn{1}{c}{ Validator } & Hasil Validasi(persen) \\
\hline 1 & Ahli Bahasa & 85 \\
2 & Ahli Materi & 100 \\
3 & Ahli Evaluasi & 90 \\
Rerata & & 91,7
\end{tabular}

Dari tabel di atas didapat nilai rata-rata validasi 91,7 dengan predikat sangat baik. Dengan demikian modul layak untuk digunakan.

3) Uji terbatas

Setelah modul divalidasi oleh ahli dan dinyatakan minimal baik, langkah selanjutnya dilakukan uji terbatas. Untuk itu emodul diujikan di kelas VIII A, dengan jumlah responsden 30 orang.

Setelah siswa dilakukan pembelajaran menggunakan modul, siswa diberikan angket dengan jumlah pertanyaan 10 item. Contoh angket yang sudah diisi siswa terlampir pada lampiran 9. Hasil pengisian angket itu direkapitulasi sebagai berikut

Tabel 2 Hasil Angket siswa dalam uji terbatas

\begin{tabular}{|l|l|l|l|l|l|l|l|l|l|}
\hline No & \multicolumn{1}{|c|}{ Pernyataan } & \multicolumn{2}{c|}{ SS } & \multicolumn{2}{c|}{ S } & \multicolumn{2}{c|}{ TS } & \multicolumn{2}{c|}{ STS } \\
\hline 1 & JML & $\%$ & JML & $\%$ & JML & $\%$ & JML & $\%$ \\
\hline & $\begin{array}{l}\text { Tampilan awal modul Car } \\
\text { Safety menarik sehingga } \\
\text { penasaran untuk segera } \\
\text { membaca nya }\end{array}$ & 9 & 30 & 21 & 70 & 0 & 0 & 0 & 0 \\
\hline 2 & $\begin{array}{l}\text { Aktifitas dalam modul car } \\
\text { safety sesuai dengan } \\
\text { materi yang disajikan. }\end{array}$ & 17 & 56 & 13 & 44 & 0 & 0 & 0 & 0 \\
\hline 3. & $\begin{array}{l}\text { Teks modul Car Safety } \\
\text { dapat dibaca dengan baik }\end{array}$ & 14 & 46 & 16 & 54 & 0 & 0 & 0 & 0 \\
\hline 4 & $\begin{array}{l}\text { Instruksi/petunjuk dalam } \\
\text { modul car safety dapat } \\
\text { dimengerti }\end{array}$ & 12 & 40 & 18 & 60 & 0 & 0 & 0 & 0 \\
\hline
\end{tabular}


Vol. 1 No. 2 Desember 2021, e-ISSN : 2807-8659 | p-ISSN : 2807-8829

\begin{tabular}{|l|l|l|l|l|l|l|l|l|l|}
\hline 5 & $\begin{array}{l}\text { Materi dalam modul Car } \\
\text { Safety sesuai dengan } \\
\text { indikator pembelajaran }\end{array}$ & 12 & 40 & 18 & 60 & 0 & 0 & 0 & 0 \\
\hline 6 & $\begin{array}{l}\text { Variasi soal dalam modul } \\
\text { Car Safety cukup beragam }\end{array}$ & 9 & 30 & 21 & 70 & 0 & 0 & 0 & 0 \\
\hline 7 & $\begin{array}{l}\text { Modul Car Safety dapat } \\
\text { membantu melatih } \\
\text { keterampilan siswa dalam } \\
\text { materi Gerak dan gaya }\end{array}$ & 16 & 54 & 14 & 46 & 0 & 0 & 0 & 0 \\
\hline 8 & $\begin{array}{l}\text { Modul car safety menarik } \\
\text { untuk digunakan dari awal } \\
\text { hingga akhi }\end{array}$ & 14 & 46 & 16 & 54 & 0 & 0 & 0 & 0 \\
\hline 9 & $\begin{array}{l}\text { Modul car safety dapat } \\
\text { digunakan sebagai } \\
\text { alternatif media belajar } \\
\text { materi gerak dan gaya } \\
\text { dengan cara } \\
\text { menyenangkan }\end{array}$ & 13 & 44 & 17 & 56 & 0 & 0 & 0 & 0 \\
\hline 10 & $\begin{array}{l}\text { Modul car safety dapat } \\
\text { meningkatkan motivasi } \\
\text { belajar fisika }\end{array}$ & 9 & 30 & 21 & 70 & 0 & 0 & 0 & 0 \\
\hline Jumlah & 125 & & 175 & & & & & \\
\hline
\end{tabular}

Selanjutnya dicari nilai respons siswa dalam skala 100.. Nilai respons siswa dapat ditentukan dengan rumus berikut.

$$
\begin{aligned}
& \text { Nilai }=\frac{\text { Skor }}{\text { Skormaksimum }} \times 100 \% \\
& \text { Nilai }=\frac{(125 \times 4)+(175 \times 3)+(0 \times 1)+(0 \times 0)}{1200} \times 100 \%
\end{aligned}
$$

$$
\text { Nilai }=85,16 \%
$$

Dari nilai yang didapat maka 85,2 termasuk predikat sangat sangat positif. Jadi dapat disimpulkan respons siswa terhadap modul adalah sangat positif

\section{Kelebihan modul Car safety berbasis STELR -STEM}

Modul ini mempunyai kelebihan karena dekat dan dapat diaplikasian dalam kehidupan sehari-hari. Warna dan tampilan modul yang lebih mudah dibaca juga sudah dikembangkan agar alat dan bahan - bahan nya lebih mudah didapatkan disekitar kita .Dengan modul ini juga pelajaran lebih mudah dipahami dengan tujuan siswa lebih tertarik dalam pengembangan sains pada diri nya dan memutuskan untuk berkarir di bidan STEM di masa mendatang

Dari seluruh kegiatan pengembangan yang telah dilakukan berikut hasil rekapitulasi pada hasil kelayakan Modul Car Safety berbasis STELR-STEM

Tabel 3 Hasil kelayakan Modul Car Safety berbasis STELR-STEM

\begin{tabular}{lll} 
No & Uji Coba & Persentase \\
\hline 1 & Ahli Bahasa & 85 \\
2 & Ahli Materi & 100 \\
3 & Ahli Evaluasi & 90 \\
4 & Uji Coba Terbatas & 85 \\
& Rerata & 90
\end{tabular}


Berdasarkan data keseluruhan pada Tabel 1, dengan hasil skor keseluruhan memperoleh $90 \%$ maka dapat dianalisis modul Car - Safety berbasis STELR-STEM dikategorikan baik dan layak. Sehingga dari keseluruhan proses dapat disimpulkan bahwa produk pengembangan pada penelitian ini telah memenuhi kriteria kelayakan.

Dari hasil uji efektivitas diketahui rata-rata nilai tes kelas control adalah 76,0 sedangkan rata-rata nilai tes kelas eksperimen adalah 87,1 . Rata-rata nilai tes kelas eksperimen lebih besar dari rata-rata nilai kelas kontrol, dengan selisih 11,0. Dengan demikian dapat disimpulkan bahwa terbukti bahwa modul efektif digunakan dalam pembelajaran.Sedangkan dari hasil angket siswa didapat skor $86 \%$ termasuk predikat sangat positif. Jadi dapat disimpulkan respons siswa terhadap penggunaan modul car safety untuk pembelajaran adalah sangat positif.

Penelitian pengembangan modul berbasis STEM pernah dilakukan pada tahun 202 berbasis STEM pada materi elektrolisis yang dilakukan oleh Syahirah (2020). Modul ini dinilai layak dan mendapat respon positif dari guru dan siswa serta dapat meningkatan minat siswa pada pelajaran elektrolisis. Juga pengembangan modul berbasis STEM pada materi Fluida statis dilakukan oleh Febriyanti (2018) yang dikatakan dinilai valid dan juga praktis digunakan.Selain itu modul ini dinilai efektif dalam meningkatkan minat siswa dan layak digunakan.

\section{KESIMPULAN}

Dari análisis Modul Car Safety berbasis STELR-STEM dalam pembelajaran IPA memiliki hasil perhitungan yang sesuai sehingga diterima oleh para ahli dan pengguna. Berdasarkan hasil persentase kelayakan mendapat hasil $90 \%$ dan juga dinilai efektif pada pembelajaran juga mendapat respon positif dari siswa. Dengan adanya modul car safety ini diharapkan pembelajaran sains dapat terasa lebih dekat dan lebih nyata dalam kehidupan siswa sehingga dapat meningkatkan minat siswa terhadap pembelajaran sains. Jadi akan lebih banyak lagi siswa yang memilih berkarir dalam bidang STEM dimasa yang akan datang .

\section{DAFTAR PUSTAKA}

Cirkony, Conny.(2014). STELR Car Safety.Perth.AU : STELR.

Febriyanti, Ervina. (2018). Pengembangan Modul Berbasis Stem (Science, Technology, Engineering, and Mathematics) Untuk Materi Fluida Statis Pada Pembelajaran Fisika Smk - Teknik Kendaraan Ringan Otomotif. From ; http://repository.unej.ac.id/handle/123456789/87878

Pentland, Peter. (2019). Training of STELR-STEM : Renewable Energy. What is STERL?. Perth.AU : STELR.

Sugiyono. (2013). Metode Penelitian Pendidikan : Pendekatan Kuantitatif, Kualitatif dan $R \& D$. Bandung: Alfabeta.

Sukardi. (2003). Metode Penelitian Pendidikan : Kompetensi dan Prakteknya. Yogyakarta : Bumi Aksara.

Supardi, U.S. (2013). Hasil Belajar Matematika Siswa Ditinjau dari Interaksi Tes Formatif Uraian dan Kecerdasan Emosional. Jurnal Formatif, Vol 3(2) : 78 - 96. Keluarga Alumni Universitas Indraprasta PGRI.

Syahirah,M.,Anwar,L,. \& Holiwarni,B. (2020).Pengembangan Modul Berbasis STEM (Science, Technology, Engineering And Mathematics) Pada Pokok Bahasan Elektrokimia 15(04) 317-324 From DOI: http://dx.doi.org/10.29303/jpm.v15i4.1602

Syukri, Muhammad. (2013). Development International Conference. Pendidikan STEM dalam "escit". Aceh:Author.

Torlakson. (2012). Innovate: ablueprint for science, technology, Engineering, and Mathematic in California : State superintendent of Public Instruction.

Wilis, Dahar, Ratna. (2006). Teori-teori belajar dan Pembelajaran. Bandung :PT Gelora Aksara Pratama .

Zulfiani, Tonih Feronika. \& Kinkin Suartini. (2009). Strategi Pembelajaran Sains. Jakarta : Lembaga Penelitian UIN Jakarta. 
Zolman Allan. (2012). Learning For STEM Literacy : Literacy STEM For Learning. Ilinois: Northern Illnois University. 